\title{
Jornalismo
}

\section{A inserção participativa dos leitores e a presença do território no Diário de Santa Maria-RS}

The participative insertion of the readers and the presence of the territory in the Diário de Santa Maria-RS

ÂNGELA CRISTINA TREVISAN FELIPPI

Professora Doutora do Programa de Pós-Graduação em Desenvolvimento Regional da Universidade de Santa Cruz do Sul (UNISC) -

Santa Cruz do Sul, RS, Brasil.

<angelafe@unisc.br>

\section{CARINA HÖRBE Weber}

Mestre em Desenvolvimento Regional pela Universidade de Santa Cruz do Sul (UNISC) - Santa Cruz do Sul, RS, Brasil.

<carinahw@yahoo.com.br>

\section{RESUMO}

Este artigo analisa o comportamento estratégico-editorial contemporâneo dos veículos jornalísticos, que têm empregado estratégias de convocação dos receptores à produção, levando em conta o território no qual circulam e valendo-se das tecnologias digitais para tal. Esse comportamento pode ser encontrado no jornal Diário de Santa Maria, pertencente ao grupo Rede Brasil Sul de Comunicações (RBS) e localizado na região central do estado

\section{ABSTRACT}

This article examines the contemporary strategic-editorial behavior of the media from the new vistas in a global context. The media have employed strategies of production and mailing of journalistic products to consumers and to territory in which they operate. This strategic behavior contemporary can be found in newspaper Diário de Santa Maria, located in the central region of the State of Rio Grande do Sul. From the mapping of sections offered 
do Rio Grande do Sul. A partir do mapeamento das seções de participação oferecidas ao leitor no jornal e da presença diária no território em que circula, busca-se entender o processo produtivo do jornal e sua relação com as questões comerciais e de circulação do periódico. Toma-se a proposta do circuito da cultura, de Richard Johnson (1999), como esquema metodológico para dar conta do estudo.

Palavras-chave: Jornalismo Impresso; Tecnologias Digitais; Circuito da Cultura. for participation and presence of the territory, having the cultural circuit of Richard Johnson's (1999) as scheme methodological, we seek to understand how is the relationship between the mode of production and economy - as the reader and the territory appear and are treated.

Keywords: Press Jornalism; Digital Tecnologies; Cultural Circuit.

$\mathrm{O}$ comportamento estratégico-editorial contemporâneo da mídia, num contexto mundial, tem indicado certa aproximação entre a produção e a recepção jornalística, intensificada por meio de estratégias voltadas à participação dos públicos consumidores e à inserção do território de circulação, empregadas pelos veículos jornalísticos, mediadas pelas novas tecnologias digitais. A globalização, a expansão das tecnologias digitais de comunicação e informação, a convergência tecnológica, o encurtamento do tempo e do espaço (Harvey, 2001), a transformação da cultura em produto mercadológico (Ortiz, 1994), a mudança da ação do Estado, a expansão da iniciativa privada e, no mercado de comunicação, o crescimento dos grupos multimídia têm interferido nos recentes modos de atuação da mídia. Da mesma forma, o necessário reposicionamento da mídia em função da competitividade existente entre os veículos de comunicação tem sido outra causa de modificações no processo produtivo do jornalismo.

Uma das modificações foi a aproximação entre os polos de produção e recepção. Os públicos consumidores passaram a dispor de mais e de novos espaços específicos 
para a participação/colaboração, num movimento que estabelece maior proximidade entre quem produz e quem recebe os produtos midiáticos. Cabe ressaltar que a participação dos públicos consumidores no processo de produção jornalística não é um fenômeno exclusivo da contemporaneidade (Gillmor, 2005). No entanto, o processo de participação, em tempos atuais, tem apresentado novos formatos a partir de elementos como a expansão tecnológica.

No Brasil, o comportamento estratégico-editorial contemporâneo da mídia tem a influência, ainda, de movimentos de abertura do mercado econômico ocorridos nas últimas décadas e que garantiram a expansão da indústria cultural nacional; e, do processo de abertura política, a partir de 1984, com a redemocratização do país, após 25 anos de ditadura militar, o que culminou na busca da população por mais espaços destinados à prática da participação civil.

Esse comportamento se desenvolve, especialmente, a partir dos anos 1990 e é encontrado, inicialmente, na grande mídia, mas se expande para veículos jornalísticos brasileiros regionais, como é o caso de um jornal regional do Rio Grande do Sul, o Diário de Santa Maria, do grupo Rede Brasil Sul de Comunicações (RBS) ${ }^{1}$. Esse jornal disponibiliza seções de participação aos públicos consumidores e espaços demarcados de visibilidade do território onde circula. O presente artigo busca identificar e analisar as estratégias mercadológico-editoriais referentes à convocação do público receptor e, do mesmo modo, analisar como o território onde o jornal circula é tratado pela produção jornalística².

\section{As estratégias mercadológico-editoriais da imprensa: popular e cidadã}

A potencialização do relacionamento entre os jornais e os leitores e o território ocorre por meio de estratégias mercadológico-editoriais próximas do que tem sido 
conceituado como jornalismo cidadão e como jornalismo popular. Esse processo se dá pelas vias do consumo, sendo o receptor/cidadão contemplado por estratégias que o relacionam ao contexto midiático-social e lhe oferecem visibilidade e pertencimento.

\section{Jornalismo cidadão}

Os primeiros indícios concretos do jornalismo cidadão se dão com um movimento surgido nos Estados Unidos a partir do public journalism, no início dos anos 1990, e do civic journalism, na década de 1970, que significa a adoção de causas sociais por parte do veículo jornalístico. Os jornais impressos reagiram impulsionados pela forte concorrência provocada pela televisão e devido à falta de maior abertura ao debate político pela mídia. Propunha-se que os meios de comunicação articulassem as demandas mais imediatas dos cidadãos (Abreu, 2003).

Se, de um lado, a mídia exerce mediações enquanto instituição social; de outro, ao fornecer possibilidades concretas de inserção participativa/civil aos públicos consumidores, permite que esses leitores/cidadãos se apropriem dos meios de comunicação para a resolução de suas demandas mais imediatas.

A crescente exposição nos meios massivos de comunicação de diferentes práticas tradicionalmente reconhecidas como práticas políticas [...] tem sido tematizada como um enriquecimento e ampliação do espaço público que contribuiria para o fortalecimento da cidadania, entre outras razões, devido a maiores possibilidades de informação da população, uma expressividade social crescente, uma maior capacidade de exercer a fiscalização e o controle dos atos do governo e de outros setores do poder."

(Mata, 2002, p. 66) $)^{3}$ 
O jornalismo cidadão, dessa forma, representa a possibilidade concreta de participação dos receptores dentro do processo produtivo do jornalismo. À medida que esses públicos têm acesso a espaços específicos para a participação e para a produção de conteúdos jornalísticos, podem exercer a cidadania ${ }^{4}$ e a democracia. A primeira experiência positiva da prática do jornalismo cidadão é a do jornal sulcoreano OhmyNews, que surgiu em 2000. Para Gillmor, jornalista norte-americano e fundador do Centro para a Mídia Cidadã,

quando qualquer um pode ser escritor, no sentido mais amplo e para um público global, muitos de nós tentaremos sê-lo. A Net está a desmentir tantas das coisas que dizíamos acerca dos media e dos modelos empresariais que mal conseguimos acompanhar as transformações; é difícil manter o equilíbrio quando está em curso a passagem de um (sic) hierarquia vertical para algo de muito mais democrático e, é certo, confuso." [grifo do autor]

(Gillmor, 2005, p. 227)

No Brasil, jornais, rádios, TVs, sites e revistas têm destinado mecanismos de participação aos públicos consumidores para a prática do jornalismo cidadão.

\section{Jornalismo popular}

Nos anos 1980, com a expansão e abertura do mercado de comunicação no Brasil, o marketing e as pesquisas de mercado passam a integrar o processo produtivo jornalístico. Somado a isso, nas últimas duas décadas, a mídia comercial tem 
empregado estratégias de participação originárias do popular para sustentar e alavancar a audiência junto a novas camadas sociais que ingressaram no consumo no país, resultado de planos econômicos e de processos de desenvolvimento, que inseriram uma fatia da população na aquisição de bens culturais e simbólicos, como é o caso do jornal impresso.

Um fenômeno dos anos 2000 foi a criação dos jornais populares, destinados às classes $\mathrm{C}$, D e E, com características específicas, mesclando o que se produzia nos anos 1980, nos jornais chamados sensacionalistas, com novas abordagens dos acontecimentos, focadas nesses públicos consumidores, e com temáticas que giram, basicamente, em torno das editorias de política, geral (forte conotação para serviços) e variedades.

O chamado jornalismo popular bebe numa matriz popular, tanto na sua estética como no discurso. Um componente importante desse jornalismo é a participação do leitor, por intermédio da disponibilização de espaços e de mecanismos que propiciam a possibilidade de sugestão de pautas, de reclamações e do próprio envio de materiais, com predomínio de notícias leves e de cunho humano. As estratégias do jornalismo popular se voltam à busca por uma maior aproximação com o leitor e estão embasadas em três elementos principais: aplicação de linguagem simples e didática aos materiais comunicacionais produzidos; oferecimento de recompensas materiais (brindes e prêmios); e, pertencimento e visibilidade aos públicos consumidores. Esse tipo de jornalismo está embasado em interesses mercadológicos, uma vez que "servir o cidadão passa a ser mais do que uma função social, torna-se uma atividade lucrativa" (Amaral, 2004, p. 19).

\section{Os mecanismos de participação}

A participação dos públicos na mídia se dá por meio de mecanismos específicos oferecidos pelos veículos de comunicação dentro do seu processo produtivo. Os 
recursos tecnológicos - e dentro deles, as tecnologias digitais - integram o processo de aproximação entre emissores e receptores ao passo que se tornam recorrentes manifestações via e-mails, comentários em blogs, sites e redes sociais e envio de imagens. No caso do jornalismo, o processo de digitalização da produção, iniciado a partir dos anos 1970, com a primeira leva de informatização das redações, e efetivado de fato no final dos anos 1980 e nos anos 1990, acabou por viabilizar a criação de estratégias de participação, ampliando as facilidades para que o receptor se tornasse ativo no processo produtivo.

No cenário contemporâneo, as possibilidades de produzir e de gerar conteúdo por parte do consumidor da informação cresceram significativamente, não só pela facilidade de acesso aos meios de produção, como câmeras fotográficas e filmadoras digitais, celulares, notebooks, entre outros, mas também pela velocidade com que esse processo pode ocorrer devido à digitalização e à transmissão de dados pela internet.

Para além das múltiplas possibilidades de participação, que vão desde a sugestão de pauta até o envio de imagens, áudio e texto (cartas, depoimentos e artigos de opinião), a geração de conteúdo por parte do receptor se encontra atrelada às propostas da política editorial do veículo. Ou seja, existe participação, mas, no geral, mediada, controlada pelo polo tradicional de produção. E, devido a questões comerciais e mesmo a um modo de fazer desse processo já estabelecido, a participação, em geral, tem se caracterizado por envolver temáticas relacionadas à prestação de serviço, à utilidade pública e à visibilidade do receptor, com destaque para reclamações em relação à ausência ou à ineficácia dos serviços públicos e à presença em colunas sociais e similares.

O chamamento à participação da sociedade civil na produção jornalística está vinculado à inter-relação existente entre produção e consumo, ao passo que se estimula o exercício da participação e se acentua o papel de mediação desempenhado 
pelos veículos jornalísticos. Como consequência, os públicos consumidores passam a encontrar na mídia a contemplação de interesses e de direitos que, num primeiro momento, seriam de responsabilidade de outras instituições, além de serem contemplados com a visibilidade e o pertencimento. Os indivíduos desempenham dois papeis: o de cidadãos, pela participação coletiva e pela democracia, e o de consumidores, pelo consumo dos meios de comunicação (Canclini, 2008).

Registram-se, desse modo, influências de cunho mercadológico nos movimentos da imprensa e um controle expressivo desta no processo de participação. Por outro lado, esse mesmo movimento parte do pressuposto de que a maior aproximação entre os emissores e os receptores potencializa a possibilidade de ocorrência da cidadania, visto que se incentiva a participação popular de diferentes maneiras.

\section{Circuito da cultura: relações entre redação, comercial e circulação}

Os produtos jornalísticos se constituem, também, em mercadorias culturais, simbólicas e capitalistas (Johnson, 1999). A partir das possibilidades concretas de participação, os públicos consumidores desempenham a função de receptores e de produtores no processo produtivo do jornalismo, o que pode ser entendido a partir do circuito da cultura proposto pelo autor que, por conseguinte, prevê a inter-relação entre o processo de comunicação, a recepção, a elaboração no social e a devolução para a mídia. O processo produtivo do jornalismo pode ser estudado a partir do circuito da cultura, que representa uma estruturação teórica para o entendimento da intersecção entre a produção jornalística, a sociedade e a economia.

O modelo de circuito da cultura engloba os momentos da produção, da circulação e do consumo dos produtos culturais. Segundo o esquema de Johnson (1999), o primeiro momento (produção) está relacionado ao processo produtivo jornalístico, o que envolve a definição de pautas, a redação de textos e a edição, dentre outras etapas. A 
produção se estende, portanto, à concretização de uma mercadoria cultural - as condições capitalistas, priorizando-se as categorias de representações públicas e de vidas privadas. O segundo momento (textos/formas) engloba o formato dos produtos culturais e o resultado do processo produtivo (formatos e gêneros jornalísticos). $O$ terceiro momento (leituras) se refere às condições de recepção e de consumo, cujas categorias são: o abstrato universal e o concreto particular. E o quarto momento (culturas vividas/ relações sociais) diz respeito aos acúmulos de significados na sociedade que serão base para a produção de outros materiais pelos meios midiáticos, como descrito na Figura 1.

O circuito da cultura se constitui do

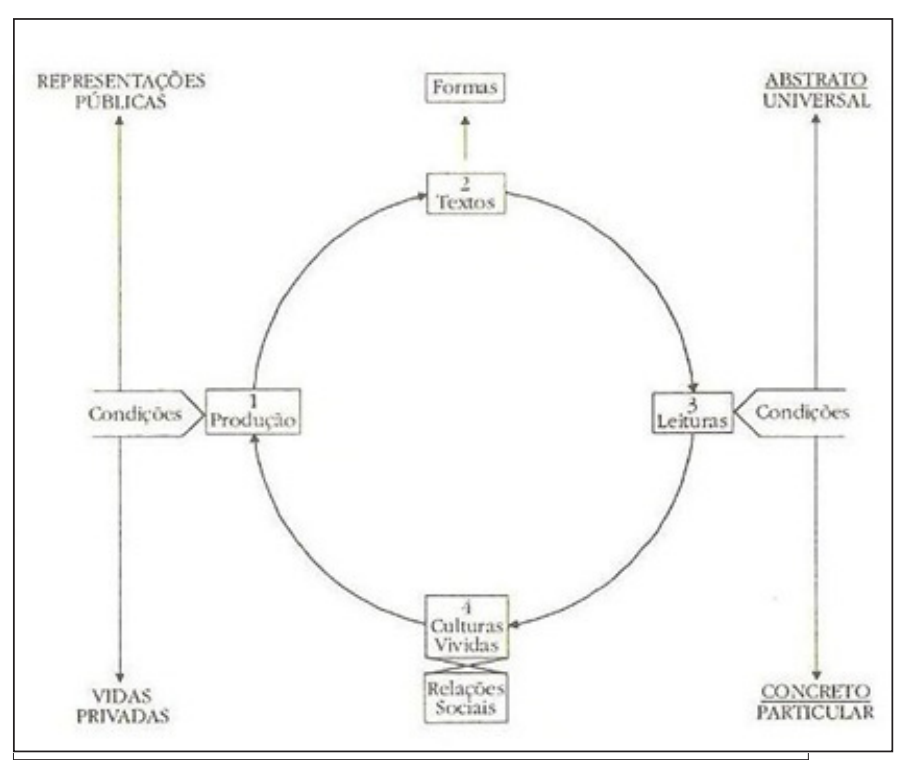

Figura 1 - Modelo de circuito da cultura de Richard Johnson

Fonte: Johnson (1999, p. 35). capital e da produção e circulação de formas subjetivas - condições culturais de produção. Os veículos jornalísticos abordam a presença dos leitores e do território a partir de um posicionamento mercadológico-editorial, por intermédio de estratégias específicas, que vão da redação ao comercial e à circulação.

\section{Diário de Santa Maria: "a leitura da cidade" e "a cara da região"5}

O jornal Diário de Santa Maria existe desde 2002. Tabloide, diário, intitula-se regional. Circula numa área que se denomina de região ${ }^{6}$ central do Rio Grande do Sul, composta por 36 municípios7, incluindo sua sede, Santa Maria. E, possui 
uma versão online, disponível no site do jornal. O Diário de Santa Maria é um dos seis jornais do Grupo RBS, o que lhe concede um satisfatório aporte. No cenário local, concorre com o jornal $A$ Razão, tradicional, porém enfraquecido editorialmente.

Nos dias de semana, o Diário de Santa Maria costuma ter de 24 a 28 páginas; no final de semana, de 34 a 48. Tem as editorias fixas: Economia e Política; Opinião e Página 2; Online e Arte; Diário 2 e Mix (variedades); Geral, Polícia e Região; e Esportes. Há, ainda, páginas temáticas: Educação, Veículos, Saúde, Na Cidade, Na Região, No País e No Mundo; e, os cadernos fixos: Quarta Colônia (microrregião dentro da área de circulação), Saúde, Kzuka no Diário (segmento jovem), Diário 2 e Revista Mix (variedades), e, Empregos, Cursos \& Concursos, encartado no caderno de Classificados. O jornal contempla, além do local e do regional, o noticiário nacional e internacional.

Quanto à circulação, dados do Instituto Verificador de Circulação (IVC) ${ }^{8}$, apontam que o Diário de Santa Maria possui uma média diária de 18.771 exemplares. Do total de exemplares, 16.289 são de assinaturas e 2.482, de venda avulsa. Conforme a coordenadora de circulação, "a circulação de assinaturas nas cidades de abrangência do jornal é em torno de $17 \%$ do total da circulação, isto é, não chega nem a $20 \%$ no interior ${ }^{9}$. A maioria está concentrada, realmente, em Santa Maria"10.

Esse é um primeiro fator interessante na análise desse jornal, explicitado na contradição dos dois slogans do jornal, apresentados no subtítulo acima. O jornal diz-se regional, porém circula predominantemente em Santa Maria ${ }^{11}$, assim como noticia muito mais sobre esse município sede do que sobre os demais que compõem sua área de abrangência ${ }^{12}$. Embora minoritária, a presença dos demais municípios é destacada por meio de: uma página semanal com notícias regionais, cujo cabeçalho recebe o título de Diário da Região; um selo nas notícias ao longo do jornal que sejam regionais; o recurso bold, grifando o nome do município noticiado; e, a retranca Mais, para notas relativas aos municípios da região relacionadas a uma notícia maior. 
Apesar de o Diário de Santa Maria se propor a abordar a região central, ou seja, todo o território onde circula, a presença da região apresenta rupturas internas, provenientes da própria linha editorial. O resultado da pesquisa Ibope 2008 acerca do Diário de Santa Maria, aponta o jornal como sendo o mais lido da região central e, ainda, o jornal que é a "cara da região"13. Por outro lado, o resultado da pesquisa e o próprio posicionamento do jornal sugerem a contradição nítida em relação ao slogan oficial do veículo - A leitura da cidade. A estrutura de cobertura regional também é frágil. Não há sucursais nos municípios, os repórteres estão todos sediados em Santa Maria e se deslocam pouco para outros municípios. A cobertura se dá basicamente por telefone e as fotografias são produzidas, quando necessário, por fotógrafos freelancers localizados nos distintos municípios.

O discurso da redação a respeito disso é contraditório. A editora-chefe do jornal, Andreia Fontana, ressalta a questão do predomínio da cidade de Santa Maria na produção jornalística: "A gente é hiperlocal"14. E, noutra fala, "a gente sempre foi um jornal regional apesar de ter essa obsessão por Santa Maria"15. Ainda, afirma Fontana,

trabalhamos uma série de ações para que a gente cresça na região. A gente acha que precisa de mais produto, ter mais matérias da região - só que, claro, para isso, precisamos de mais gente para fazer mais matérias na região. O que a gente precisa melhorar é a logística, porque a gente chega tarde à região, a entrega é tarde na região. Porque também não adianta ter produto, mas chegar depois do meio-dia nas cidades da região. E a gente precisa também vender anúncios para a região. Tudo isso está ligado para que a gente consiga ampliar essa cobertura regional."16 
O jornal estabelece um tipo de relação com o território que o valoriza na dimensão de seu retorno. Parece dar aos municípios do entorno de Santa Maria uma parte pequena da sua produção editorial, correspondente, talvez, à contrapartida de assinaturas e venda avulsa que esses municípios têm e até menos do retorno publicitário ${ }^{17}$. No entanto, cria em suas páginas artifícios de hipervalorização da presença dos lugares e das suas populações que estão praticamente ausentes da publicação. O Diário, portanto, ocupa um lugar de jornal regional sem de fato cumprir com sua contrapartida como tal, que é fornecer informação, gerar o debate público, garantir a visibilidade do território como um todo que cobre. Como diz Haesbaert (2007, pp. 20-21): “Território, assim, em qualquer acepção, tem a ver com poder, mas não apenas ao tradicional 'poder político'. Ele diz respeito tanto ao poder no sentido mais explícito, de dominação, quanto ao poder no sentido mais implícito ou simbólico, de apropriação".

Há um embate entre o local e o regional nas páginas do Diário, que vem sendo vencido de longe pela dimensão do local, por uma série de fatores: uma cultura jornalística de cobertura da cidade em detrimento do município, e, da cidade sede do jornal em relação ao espaço maior de circulação; a falta de investimento infraestrutural e humano para garantir uma cobertura mais equilibrada no território; a relação estabelecida entre retorno publicitário e cobertura editorial; e, a dificuldade em estabelecer uma estrutura de circulação que garanta a chegada do jornal nos mais distantes locais do território abrangido.

\section{Aproximação com o leitor}

A presença do leitor no Diário de Santa Maria é constante. A redação recebe quantidade significativa de e-mails, telefonemas e até visitas de leitores, que colaboram de alguma forma com o jornal. 
O Diário de Santa Maria tem estratégias de aproximação com os públicos consumidores no formato das seguintes seções de participação ${ }^{18}$ : Santa Maria Quer Saber, traz questionamentos e perguntas acerca de temas em geral. Os leitores podem participar da seção enviando e-mails e cartas; O Nome é uma seção dedicada a pessoas anônimas. Traz informações sobre a vida pessoal e profissional da pessoa escolhida; Enquete faz referência a algum assunto com cobertura realizada pelo jornal; Frases da Página 2 traz citações de reportagens do jornal. Podem ser frases provenientes de personalidades ou de pessoas anônimas/ comuns; Foto da Página 2, é uma seção em que os materiais provêm de fotógrafos da equipe de redação e de leitores. Quando as fotos são enviadas ao jornal por leitores (arquivo pessoal) não há remuneração pelo trabalho e é necessário que o leitor autorize a publicação para todos os veículos do Grupo RBS; Mascotes contempla informações dadas por pessoas que têm um animal e desejam mostrá-lo no jornal; Quero um Dono tem notícias de animais disponíveis para adoção; Queremos um Dono traz notícias de animais para doação; Cadê meu Dono? possui informações sobre animais perdidos; Obituário, feito pelos repórteres do jornal, mas contando com a participação do leitor que, eventualmente, pode pedir espaço para homenagear algum falecido; Tem Conserto? é uma seção composta de uma fotografia acompanhada do problema constatado. Tem o formato de um pequeno texto com o problema e a resposta do órgão responsável pela solução, geralmente, o poder público. As seções Mascotes, Quero um Dono, Queremos um Dono, Cadê meu Dono?, Obituário e Tem Conserto? são publicadas na página de serviço Dia a Dia ${ }^{19}$. Há, ainda, as seções: Foto do Leitor, publicada na coluna social do jornal, de segunda a sexta, trazendo fotos enviadas por leitores; De tudo: dentro do caderno Diário 2, há uma seção titulada Almanaque. Nesta seção, consta a De Tudo - que comporta, alternadamente: poesias, crônicas, homenagens, fotos 
antigas, curiosidades, dados históricos, piadas, entre outros. Os leitores podem enviar poesias, crônicas e textos; Memória, ainda dentro da seção Almanaque, comporta textos de cunho histórico. Em alguns momentos, há alternância dessa seção com outra, a Para Rir, com piadas; Carta/E-mail e Artigos está localizada dentro da editoria de Opinião e Página 2; Ideias, um espaço para artigos, no fim de semana, na revista Mix. Os materiais podem ser enviados por leitores ou por profissionais.

Existem, do mesmo modo, espaços na versão online do Diário de Santa Maria que não são publicados na versão impressa. É o caso dos blogs Livro de Receitas do Diário, Bastidores do Diário, Blog do Meio Ambiente e Diário de Fotógrafo, que não estão vinculados a colunas publicadas na versão impressa. $O$ retorno da participação nesse espaço, pelos leitores, ocorre por meio de sugestões e pela ferramenta "comentários" - disponibilizada em cada post publicado; há também o Mural, onde o leitor pode deixar um comentário ou sugestão sobre algum assunto pontual; e, Comentários nos Blogs, sendo que as manifestações recebem filtragem dos blogueiros, antes de serem publicadas - o que pode ser publicado e o que não pode.

Apesar da participação do leitor estar institucionalizada, o jornal não sistematiza o número de participações, nem sobre as formas mais utilizadas pelo leitor, e não dispõe de cadastro desse leitor, apenas alguns dados empíricos que os jornalistas dominam. Desta forma, percebem quais seções têm mais adesão por parte dos leitores e as que não têm e se trabalha na produção com essas informações. Em relação aos critérios de seleção do material que chega à redação, a editora-chefe do Diário de Santa Maria explica: 
Às vezes é uma briga entre dois vizinhos; é um problema pontual de uma pessoa com uma empresa. Então, a gente avalia qual é o interesse - qual o interesse que o leitor do Diário de Santa Maria pode ter. Às vezes, a pessoa quer falar de um problema, mas não quer se identificar - inviabiliza a produção da matéria. Nós tentamos sempre transformar em alguma matéria, algo no jornal - às vezes, não necessariamente do tamanho que a pessoa gostaria que tivesse. Às vezes, também não sai com a rapidez que a pessoa gostaria, mas eu acho que nos procuram bastante e a gente consegue privilegiar bastante, na medida do possível." 20

A partir do mapeamento das seções de participação e do acompanhamento na redação, pode-se chegar a algumas conclusões a respeito das questões que esse artigo visa tratar. Uma delas é que as tecnologias digitais de comunicação e informação têm viabilizado a maior participação do receptor. No Diário a existência de uma versão digital do jornal faz com que o leitor participe do impresso por meio do online. As ferramentas do online atuam como canais de aproximação do leitor - e-mails específicos para o envio de texto e imagem e redes sociais permitem que o leitor opine e disponibilize materiais como cartas, artigos, poesias, crônicas, comentários e fotografias.

Outra constatação dá conta de que a participação proporcionada pelo jornal caminha muito mais para a garantia de visibilidade do leitor do que propriamente para uma participação que busca o acesso à voz, a direitos civis, à solução de problemas ou embate de ideias por meio do debate público. Isso se comprova pelo número de espaços destinados à publicação de fotos (coluna social) e à divulgação pessoal (seção 
O Nome, por exemplo). São movimentos relacionados à tendência do jornalismo contemporâneo de agregar o entretenimento e a espetacularização nas notícias, e, também, ao que diz Morin (1999) sobre a existência de uma valorização excessiva do universo do lar e da vida privada na mídia. Esse tipo de inserção causa atração e curiosidade do público consumidor, mexe com a opinião pública, pode comover e incentivar a resolução de problemas do cotidiano. As seções destinadas ao envio de fotografias pessoais e de animais têm características do jornalismo cidadão e, ainda, elementos nítidos provenientes do jornalismo popular.

\section{Considerações finais}

A participação do leitor e a inclusão do território no Diário de Santa Maria se embasam na tríade entre redação, comercial e circulação, visto que são formulados produtos jornalísticos e capitalistas, o que pressupõe a articulação entre o modo de produção do jornalismo e a economia. O jornal, enquanto mercadoria pertencente a um sistema capitalista, se inter-relaciona à sociedade, à cultura e ao produto final.

O emprego dos recursos tecnológicos, aliado ao processo produtivo, integra o movimento mundial da mídia na contemporaneidade, que prevê maior aproximação entre emissores e receptores. Dessa forma, o jornal tem investido nesse paralelo como um elemento para interagir com seus públicos consumidores e com seu território de abrangência. Esse movimento tem embasamento mercadológico e integra o projeto estratégico-editorial do periódico - o que está enraizado na própria equipe, que tem responsabilidades de manutenção e de abastecimento do noticiário na versão online do jornal, além da versão impressa.

O relacionamento com os leitores e com o território, no Diário de Santa Maria, tem influências que vão desde as rotinas produtivas aos valores-notícia e à cultura dos profissionais - o que contempla a produção dos conteúdos jornalísticos enquanto 
produtos - até a venda e a distribuição dessas mercadorias culturais, capitalistas e simbólicas formuladas. Esses aspectos indicam como a produção busca o território e como o território participa, elementos que serão discutidos adiante.

\section{REFERÊNCIAS}

ABRAMOVAY, Ricardo. Bases para a formulação da política brasileira de desenvolvimento rural: agricultura familiar e desenvolvimento territorial. Brasília: IPEA, 1998.

ABREU, Alzira Alves de. Jornalismo cidadão. Estudos Históricos. Rio de Janeiro, v. 1, n. 31, pp. 25-40, jan./jun. 2003. Disponível em: <http://virtualbib.fgv.br/ojs/index.php/reh/article/view/2185/1324>. Acesso em: 06 out. 2007.

AMARAL, Márcia Franz. Lugares de fala do leitor no Diário Gaúcho. 2004. 273 f. Tese (Doutorado em Comunicação e Informação) - Faculdade de Biblioteconomia e Comunicação, UFRGS, Porto Alegre, 2004.

BASTIDORES DO DIÁRIO. Disponível em: <http://wp.clicrbs.com.br/bastidoresdodiario/?topo=52,1,1, 165,e165>. Acesso em: 13 dez. 2010.

CANCLINI, Néstor García. Consumidores e cidadãos: conflitos multiculturais da globalização. Rio de Janeiro: UFRJ, 2008.

CAPPARELLI, Sérgio; LIMA, Venício. Comunicação e televisão: desafios da pós-globalização. São Paulo: Hacker, 2004.

CARVALHO, José Murilo de. Cidadania no Brasil: o longo caminho. Rio de Janeiro: Civilização Brasileira, 2001. COVRE, Maria de Lourdes Manzini. O que é cidadania. São Paulo: Brasiliense, 1995.

DIÁRIO DE SANTA MARIA. Disponível em: <http://www.clicrbs.com.br/especial/rs/dsm/capa, 14,225,0,1365,Capa.html>. Acesso em: 25 out. 2013.

GILLMOR, Dan. Nós, os media. Lisboa: Presença, 2005.

GRUPO RBS. Informações sobre a empresa. Disponível em: <http://www.rbs.com.br/quem_somos/index. php?pagina=grupoRBS>. Acesso em: 25 out. 2013.

HAESBAERT, Rogério. Território e multiterritorialidade: um debate. GEOgraphia. Rio de Janeiro, v. 9, n. 17, pp. 19-45, jan./jun. 2007. Disponível em: <http://www.uff.br/geographia/ojs/index.php/geographia/ article/view/213/205>. Acesso em: 20 set. 2010. 
HARVEY, David. Condição pós-moderna: uma pesquisa sobre as origens da mudança cultural. São Paulo: Loyola, 2001.

JOHNSON, Richard. O que é, afinal, Estudos Culturais? In: SILVA, Tomaz Tadeu da (Org.). O que é, afinal, Estudos Culturais? Belo Horizonte: Autêntica, 1999. pp. 7-131.

CORRÊA, Roberto. Trajetórias Geográficas. Rio de Janeiro: Bertrand Brasil, 1997.

MARTINS, Luiz. Um gênero que o Brasil começa a conhecer. Observatório da Imprensa, n. 174, 29 mai. 2002. Disponível em: <http://www.observatoriodaimprensa.com.br/artigos/jd290520023.htm>. Acesso em: 20 out. 2010.

MATA, Maria Cristina. Comunicación, ciudadanía y poder: pistas para pensar su articulación. Revista Diálogos de la Comunicación, Colômbia, n. 64, pp. 64-75, dez. 2002.

MORIN, Edgar. Cultura de massas no século XX: necrose. Rio de Janeiro: Forense Universitária, 1999.

ORTIZ, Renato. Mundialização e cultura. São Paulo: Brasiliense, 1994.

SILVEIRA, Maria Laura. Região e Globalização: repensando um esquema de análise. REDES. Santa Cruz do Sul, v. 15, n. 1, pp. 74-88, jan./abr. 2010. Disponível em <http://online.unisc.br/seer/index.php/redes/ issue/view/71>. Acesso em: 05 jan. 2011.

\section{NOTAS}

1 Segundo dados do site da empresa, o Grupo RBS foi fundado em 31 de agosto de 1957. Possui, ao todo, 18 emissoras de TV aberta, afiliadas à Rede Globo; duas emissoras de TV locais; 24 emissoras de rádio; oito jornais; 11 produtos na plataforma digital; duas empresas de eventos; operação mobile marketing; operação segmento rural; operação segmento jovem; operação e-business; uma editora; uma gravadora; uma gráfica; uma empresa de logística; uma empresa de educação executiva e a Fundação Maurício Sirotsky Sobrinho. Disponível em: <http://www.rbs.com.br/quem_somos/index.php?pagina=grupoRBS>. Acesso em: 25 out. 2013.

2 Este artigo utilizou como técnicas de coleta de dados de campo o mapeamento das seções de participação por meio do acompanhamento documental do jornal, da observação do processo produtivo do Diário de Santa Maria (permanecendo na redação do jornal por uma semana, de $1^{\circ}$ a 07 de novembro de 2010) e de entrevistas em profundidade com editores e repórteres.

3 Tradução das autoras.

4 No dizer de Covre (1995), a cidadania tem relação com o surgimento da vida na cidade e com a capacidade de os homens exercerem seus direitos e seus deveres de cidadãos. As primeiras concepções acerca de cidadania são originárias da Grécia e da Roma Antigas. Conforme Carvalho (2001), a cidadania, numa 
acepção moderna, inclui três direitos: civis (os fundamentais à vida, à liberdade, à propriedade e à igualdade perante a lei); políticos (ao voto e à participação no governo da sociedade); e, sociais (à educação, ao trabalho, a um salário justo, à saúde e à aposentadoria). O autor toma como base uma das concepções mais clássicas sobre cidadania, a do sociólogo inglês Thomas Humphrey Marshall (1967).

5 Caracterização que integra o arquivo titulado Defesa DSM (Defesa Diário de Santa Maria), de 2010, utilizado pelo departamento Comercial do Diário de Santa Maria e que contém dados de pesquisa realizada pelo Instituto Brasileiro de Opinião Pública e Estatística (IBOPE), em 2008, sobre o jornal. Nesse item, o jornal é definido como o "mais lido da região central do estado", qual seja, um jornal voltado à região central do estado do Rio Grande do Sul: “O jornal que é a cara da região" (Defesa DSM, 2010, p. 4-5).

6 Compreende-se região como sendo o conjunto de relações culturais entre um grupo e um lugar particular ou o fruto da apropriação simbólica de uma porção de espaço por um determinado grupo (Correa, 1997). Para Silveira (2010, pp. 77-78), região "mais do que nunca, é resultado de interdependências e de uma oposição dialética entre uma ordem global e uma ordem local, com a mediação tantas vezes sem defesa da formação socioespacial. Nesse retrato, a ordem global surge como autorreferenciada, já que sua finalidade é o próprio mercado global, enquanto a ordem local pode abrigar o sentido da vida social. Na região, se desenvolve o trabalho solidário e conflitivo na copresença, na contiguidade, no cotidiano, que hoje revela a falta de coincidência entre a escala da técnica e a escala da política".

7 Agudo, Caçapava do Sul, Dilermando de Aguiar, Dona Francisca, Faxinal do Soturno, Formigueiro, Itaara, Itacurubi, Ivorá, Jaguari, Jari, Júlio de Castilhos, Lavras do Sul, Mata, Nova Esperança do Sul, Nova Palma, Paraíso do Sul, Pinhal Grande, Quevedos, Restinga Seca, Rosário do Sul, Santa Margarida do Sul, Santa Maria, Santana da Boa Vista, Santiago, São Gabriel, São João do Polêsine, São Martinho da Serra, São Pedro do Sul, São Sepé, São Vicente do Sul, Silveira Martins, Toropi, Tupanciretã, Unistalda e Vila Nova do Sul.

8 Pesquisa do IVC sobre médias mensais de circulação líquida paga, por edição, do mês de setembro de 2010, encomendada pelo jornal Diário de Santa Maria. Santa Maria: set. 2010. Os dados se referem ao período em que o artigo foi elaborado.

9 A redação denomina os municípios da região de circulação, com exceção de Santa Maria, de interior.

${ }^{10}$ Entrevista, realizada pelas autoras, com a coordenadora de circulação do jornal Diário de Santa Maria, Karine Bruch, em 2010.

${ }^{11}$ Em que pese a existência de uma edição online, que desterritorializa o jornal, a produção do Diário mantém o foco editorial na região de circulação do impresso.

${ }^{12}$ A análise não realizou medição quantitativa do conteúdo do jornal, mas o mapeamento das seções de participação realizado permitiu observar empiricamente o conteúdo do periódico.

${ }^{13}$ Informações da Defesa Diário de Santa Maria, arquivo do departamento Comercial do Diário de Santa Maria, com base em dados da Pesquisa Ibope 2008 sobre o jornal. Santa Maria: 2010. 
${ }^{14}$ Entrevista, realizada pelas autoras, com editora-chefe do jornal Diário de Santa Maria. Andréia Fontana, em 2009.

${ }^{15}$ Entrevista, realizada pelas autoras, com editora-chefe do jornal Diário de Santa Maria. Andréia Fontana, em 2010.

${ }^{16}$ Entrevista, realizada pelas autoras, com editora-chefe do jornal Diário de Santa Maria. Andréia Fontana, em 2010.

${ }^{17} \mathrm{O}$ artigo não se propôs a fazer o levantamento entre a quantidade de anúncios regionais e os dados sobre os valores em publicidade oriundos de fora de Santa Maria não foram fornecidos pelo jornal.

${ }^{18}$ O Diário de Santa Maria também possui espaços de participação esporádicos e eventuais, tais como, os concursos, Desenhe o Natal - que já teve três edições, e, Desenhe a Páscoa - lançado no ano de 2011. Ambos os concursos culturais são destinados ao público infantil e envolvem o envio de desenhos alusivos às respectivas datas religiosas, por crianças de até 11 anos. São escolhidos e premiados os trabalhos mais criativos. Há também o Vestibulog, blog sobre a temática vestibular com informações gerais, dicas de professores, resumos, entre outros. Foi disponibilizado de 06 de dezembro de 2010 a 08 de janeiro de 2011. Além desses: 50 anos da UFSM - Orgulho de Santa Maria: um mural especial alusivo ao cinquentenário da Universidade Federal de Santa Maria, em que os leitores podem deixar mensagens e homenagens à universidade.

${ }^{19}$ Baseada em e-mails recebidos pelos repórteres e na divulgação de serviços e de informações gerais como: vagas de trabalho, resultados de loterias, participação de nascimentos, cursos, entre outros.

${ }^{20}$ Entrevista, realizada pelas autoras, com editora-chefe do jornal Diário de Santa Maria. Andréia Fontana, em 2010.

\author{
Endereço das autoras: \\ Ângela Cristina Trevisan Felippi <angelafe@unisc.br> \\ Av. Independência, 2293 \\ CEP 96815-900, Santa Cruz do Sul, RS, Brasil \\ Carina Hörbe Weber <carinahw@yahoo.com.br> \\ Sindicato dos Metalúrgicos de Santa Cruz do Sul \\ Rua Fernando Abott, 983 - Centro \\ CEP 96810-148, Santa Cruz do Sul, RS, Brasil
}

Universidade de Santa Cruz do Sul - Departamento de Comunicação Social 